\title{
TEACHERS' EDUCATION IN ROMANIA CASE STUDY: BUCHAREST UNIVERSITY OF ECONOMIC STUDIES IN ROMANIA
}

\author{
Maria Liana Lacatus \\ Assoc. Prof. Dr., Bucharest University of Economic Studies, Romania, maria.lacatus@dppd.ase.ro
}

\begin{abstract}
Teacher education is a controversial issue in Romania today. It is an important subject in the debates in academia, in practitioners' groups, and in mass-media. Teacher education is viewed as being related to the quality of education, and is considered to be one of the most influential factors affecting educational quality by representatives of different interest groups and other decision makers. This is why alternatives and best practices in the field of teacher education are re-examined and re-valued. This paper will describe teacher education at the Bucharest University of Economic Studies, with emphasis on the education of teachers of economics and business. The Bucharest University of Economic Studies is one of the most important universities in Romania and the most important economic university. It was established in 1913 by Royal Decree and in its over 100 years of existence has provided higher and in-depth knowledge in the field of economics sciences, while preparing generations of economists. In addition to its mission of preparing professionals for economic activity and public administration functions, the Bucharest University of Economic Studies prepares economics and business teachers who contribute to the economic education of the Romanian population. The paper presents the activities and the programs designed by the Department of Teacher Education at the university, formerly the Pedagogical Seminar. The Pedagogical Seminar began to function soon after the founding of the university, and today the Department of Teacher Education educates teachers of both economics and business. The analysis of data collected with respect to the learning outcomes of pre- service and in-service teachers of economics and business is used to drive conclusions related to the quality of the programs and to identify positive experiences that can be shared in similar academic communities.
\end{abstract}

Keywords: Teachers' education, teachers' education programs, economic education and teachers' education, in-service teacher training.

\section{INTRODUCTION}

Teacher education is a controversial issue in Romania today. It is an important subject in the debates in academia, practitioners' groups and in mass-media. Teacher education is seen as a key component of the quality of education and is considered by representatives of different interest groups and decision makers as having the potential to be one of the most effective factors that can positively impact the quality of education.

Basically, discussions are focused on the controversial issue of how to train teachers: simultaneously or consecutively in bachelor and master programs provided by universities (Coalitia pentru educatie, 2016). The present discussions have roots in the negative perception of the public regarding the educational system and the public school learning outcomes. People complain about the lack of discipline, achievements and motivation in many public schools, and consider that one of the main causes of all these problems is the quality of teaching and, sometimes, the quality of the teachers themselves (Badescu et al, 2017). Important 
international studies document the low achievements of the educational system (OECD, 2015). Fifteen-year old Romanian students internationally tested on reading, math and science through the Program for International Student Assessment (PISA) did not perform satisfactorily. Their scores are much below the EU average of 28, with about half of them are under the performance level two out of 5 or 6 levels, which is below the level of "functional literacy".

The educational experts and representatives of different interest groups such as parents or employers are asking for a change in the system of teacher training (Romania educata, 2018). This is why alternatives and best practices in the field of teacher education field are re-examined and re-valued.

\section{TEACHERS' EDUCATION PROGRAMS}

Teacher education programs are focused on developing teaching competences in areas such as lesson planning, teaching methods and strategies, assessment, curriculum and educational materials development, communication, class management, counselling, educational decision making, and character development. The competencies also include leadership skills a teacher should have derived from the roles of instructional manager, caring person, expert learner, and cultural and civic person (Caena, 2011). Three main areas of competencies are identified to be: working with others, working with knowledge, technology and information, and working in and with society (European Commission, DG Education and Culture, 2005).

At present, universities in Romania are responsible for teacher education. They have departments specialized in teacher training. A teacher education program should have $60 \mathrm{ECTS}$, which is equivalent to one year of study. Teacher education programs focus on psycho-pedagogical subjects. In order to graduate from a teacher education program, students have to take courses such as psychology, pedagogy, didactics, and subject teaching methods. By definition, these are the more pedagogical subjects. In addition, they have to take non-traditional courses such as sociology and philosophy of education, ITC, or communication. Teachers are initially trained by enrolling students in special designed teacher education programs in addition to and simultaneously with the bachelor and master programs they are attending at university. While acquiring knowledge and skills in order to be specialized in particular domains of knowledge and acquiring competences as specialists in different industries, students can choose to attend psycho-pedagogical courses that will allow them to get a teaching certificate too.

Teacher education is based on a national curriculum approved by the Ministry of Education. These are unique national plans each university has to apply. Accordingly to these plans a fully 60 ECTS teacher education program means actually graduating from two 30 ECTS psycho-pedagogical programs: a so called Level 1 program simultaneously with or consecutively to a bachelor's program and a Level 2 program simultaneously with or consecutively to a master's program. The Level 1 program develops teaching competences required in compulsory education, which basically means to teach in middle school. The Level 2 program develops teaching competences required in non-compulsory education, which basically means, to teach in high schools (Table 1: Initial teacher training programs).

Table 1: Initial Teacher Training Programs

\begin{tabular}{|c|c|c|}
\hline Program & Beneficiaries & Qualification \\
\hline Level 1 initial teacher training & $\begin{array}{c}\text { Students enrolled in bachelor } \\
\text { programs } \\
\text { Graduates of a bachelor program }\end{array}$ & $\begin{array}{c}\text { Teacher in secondary } \\
\text { compulsory education, basically } \\
\text { middle school teacher }\end{array}$ \\
\hline Level 2 initial teacher training & $\begin{array}{c}\text { Students enrolled in master } \\
\text { programs }\end{array}$ & $\begin{array}{c}\text { Teacher in secondary non- } \\
\text { compulsory education, basically } \\
\text { high school teacher }\end{array}$ \\
\hline
\end{tabular}

Source: Data collected by the author

In a Level 1 program students are required to take courses such as psychology of education, pedagogy, didactics of specialties, classroom management and ICT assisted teaching. Particular focus is given on having experience in schools. Students have to go in schools to observe classes, study educational materials and school documents, plan lessons, assist teachers, and, finally, teach. A practical stage in a school lasts 12 or 14 weeks, depending on the length of the semester (in the $3^{\text {rd }}$ year Stage 1: 14 weeks in the $1^{\text {st }}$ Semester and Stage 2: 12 weeks in the $2^{\text {nd }}$ Semester). The students' activities in schools are supervised by tutors and faculties. 
As mentioned earlier, at the end of Level 1 program students will have 30 ECTS. Level 1 provides basic psycho-pedagogical knowledge and skills. Level 2 courses represent in-deep studies and extensions of Level 1 courses such as: adults, youngsters and teenagers' psycho-pedagogy, didactics of domains and developments in didactics of specialties, and educational programs planning and management. These are compulsory courses. In addition, there are optional courses from which students have to choose two: one from a $1^{\text {st }}$ set of subjects (educational communication, integrated education, educational counselling, and educational research methodology) and one from a $2^{\text {nd }}$ set of subjects (school management, intercultural education, sociology of education, educational policies, and contemporary pedagogical theories). At the end of Level 2 program students will have an additional 30 ECTS. In total, graduating from the Level 1 and the Level 2 programs means gaining 60 ECTS.

In-service teachers are trained too. This is part of what is called continuous teacher training and includes professional and career development or teaching degrees programs. (Table 2: Continuous teacher training).

Table 2: Continuous Teacher Training

\begin{tabular}{|c|c|c|}
\hline Program & Beneficiaries & Qualification/certification \\
\hline $\begin{array}{c}\text { Definitive as a teacher in } \\
\text { education certification / on-the } \\
\text { job confirmation (provided by } \\
\text { the local school inspectorates) }\end{array}$ & $\begin{array}{c}\text { Teachers at the beginning of their } \\
\text { teaching career, usually, at the } \\
\text { end of the first year of teaching. }\end{array}$ & $\begin{array}{c}\text { Definitive as a teacher in } \\
\text { education }\end{array}$ \\
\hline $\begin{array}{c}2^{\text {nd }} \text { teaching degree certification } \\
\text { (provided by universities) }\end{array}$ & $\begin{array}{c}\text { At least } 4 \text { years definitive as a } \\
\text { teacher in education }\end{array}$ & $2^{\text {nd }}$ degree teacher \\
\hline $\begin{array}{c}1 \text { st teaching degree certification } \\
\text { (provided by universities) }\end{array}$ & $\begin{array}{c}\text { At least } 4 \text { years } 2^{\text {nd }} \text { degree } \\
\text { teachers }\end{array}$ & 1st degree teacher \\
\hline $\begin{array}{c}\text { Other teacher training programs } \\
\text { (provided by local teacher } \\
\text { training centers, universities, or } \\
\text { different private teacher training } \\
\text { providers) }\end{array}$ & Teachers, in general & $\begin{array}{c}\text { Attending certificate } \\
\text { Professional credits certificate } \\
\text { Post-graduation certificate } \\
\text { Qualification certificate issued } \\
\text { under regulations of The } \\
\text { National Qualification Authority }\end{array}$ \\
\hline
\end{tabular}

Source: Data collected by the author

Teaching degrees programs are provided by universities. There are career development centers for teachers. The $2^{\text {nd }}$ teaching degree can be obtained by experienced teachers who can prove teaching competences at a high level. That means that they have to pass two exams: a written one from didactics of specialties topics and an oral one from psycho-pedagogy topics. In order to pass these exams, the candidate teachers have to obtain a minimum 8 grade on a scale from 1 to 10 . Each year universities organize $2^{\text {nd }}$ degree programs to allow all interested teachers to obtain it. It is not compulsory to have, but almost all teachers would like to have it mainly because it represents a higher position in the teaching career. In addition, $2^{\text {nd }}$ degree teachers are rewarded by an increase in salary.

The $1^{\text {st }}$ teaching degree program takes two years. Teachers have to pass an admission exam and write and publicly present a paper to demonstrate their interest in the subject matter and the capacity to use new subject knowledge in their current activities in class. The focus of the $1^{\text {st }}$ degree program is the competence of teachers to innovate during the educational process, with special emphasize on teaching activities. These should be demonstrated in class, while teachers are observed by experts from universities and local school authorities (inspectorates) designated as evaluators in charge of issuing $1^{\text {st }}$ teaching degrees.

In the absence of available data regarding the number of teachers with teaching degrees at the national level, we present below the situation in a commercial high school in the capital city of Romania as an example of a possible situation in schools (Table 3: Teaching degrees at V. Madgearu Commercial High 
School in Bucharest). This is a particular situation which might not be generalized because we are unable to provide data to support such a generalization. As well, research demonstrates that urban schools have a better situation in terms of human resources compared to rural schools (Badescu et al, 2017, ISE, 2015) and it is expected that many of the best teachers in the country or at least in the region will be employed in the capital city. But even so, data provided below may offer an image of the teacher interest for teaching degrees in Romania.

Table 3: Teaching degrees at V. Madgearu Commercial High School in Bucharest

\begin{tabular}{|c|c|c|}
\hline Category of teachers & Number of teachers & Percentage \\
\hline Doctors & 7 & 9.09 \\
\hline $1^{\text {st }}$ degree teachers & 41 & 53.25 \\
\hline $2^{\text {nd }}$ degree teachers & 10 & 12.99 \\
\hline Definitive as teachers in education & 17 & 22.08 \\
\hline Total & 77 & 100 \\
\hline
\end{tabular}

Source: Col. Ec. Virgil Madgearu, Bucuresti. Raport anual de evaluare a calitatii, 2017-2018, la http://www.madgearu.ro/documente/RAEI_2017-2018.pdf

As we can see, more than $75 \%$ of the teachers in the school have teaching degrees $\left(\mathrm{PhD}\right.$, and $1^{\text {st }}$ and $2^{\text {nd }}$ teaching degree). In pre-university education, a PhD is equivalent to a 1st teaching degree at the teacher's request and following a specific procedure. The situation differs mainly due to the age of the teachers (young teachers may not have teaching degrees) and teaching experience (at least nine years of teaching are required to be a $1^{\text {st }}$ degree teacher). Schools less well situated in terms of location, profile, and attractiveness both for students and teachers may have fewer $1^{\text {st }}$ and $2^{\text {nd }}$ degree teachers.

The only compulsory teaching degree is the definitive one. All the others are the teacher's choice. But, the teaching career is a prestige-motivated one and, in addition to increases in teaching status, teaching degrees also mean an increase in the teacher's salary. In general, despite the stress involved with exams, due to the increased status and salary, almost all teachers choose to attend teaching degrees programs and to get teaching degrees. The prestige and income effect of the teaching degrees is higher than the stress effect.

\section{TEACHERS' EDUCATION AT THE BUCHAREST UNIVERSITY OF ECONOMIC STUDIES}

We have conducted a research on the main characteristics of the teacher education programs provided at The Bucharest University of Economic Studies (ASE) based on data analysis regarding the economics and business teachers' education programs at the Teacher Training Department (TTD).

\section{Hypothesis}

Our hypothesis was that at ASE there is a valuable experience that can positively contribute to define a model of teacher education in Romania.

\section{Methods}

We have collected data regarding the teacher education at ASE over 100 years of existence of this higher education institution by analyzing the documents collection and monographies available at the university. We have also analyzed data available at the TTD regarding the initial and continuous teacher education.

\section{Findings}

The Bucharest University of Economic Studies (ASE) is one of the most important universities in Romania and the most important economics university. In 2011 it was classified as a university for advanced research and education, the top category of universities in Romania. It is also one of the largest universities in the country with more than 22,000 students enrolled in bachelor, master, doctoral, postgraduate, and postdoctoral programs (Istudor, 2017). It was established in 1913 by Royal Decree and in its over 100 years of existence has provided higher and in-depth knowledge in the field of economics sciences and has 
prepared generations of economists. In addition to its mission of preparing professionals for economic activity and public administration functions (Davidoglu, 1913), the Bucharest University of Economic Studies prepares economics and business teachers who contribute to the economic education of the Romanian population.

\subsection{About 100 Years of Experience in Economics and Business Teachers' Education}

The Pedagogical Seminar, the predecessor of the present Teacher Training Department (TTD), began to function soon after the university was established (Năstase, Roșca, 2013). Students enrolled in psychopedagogical programs have benefitted, in addition to a strong preparation in economics, to a high quality pedagogical experience with many becoming dedicated teachers or professors.

At The High Academy of Commercial and Industrial Studies (AISCI), as it was called before the present ASE, in the first year of its existence, 600 students were enrolled, 107 among them being foreigners (Năstase, Roșca, 2013). They were studying economics, in general, to prepare for a career in the economic or public administration domain. At that time, economic education was seen as education for economic activity with a larger practical and realistic dimension. Besides an economic background, students gained a scientific background in the fields of mathematics, physics, and chemistry. In addition, they were required to study geography, modern languages, and shorthand and typing.

The pedagogical courses were organized mainly for the students who were thinking to have a teaching career at the pre-university level, in a commercial high school. But, all the AISCI students, graduates, and doctors could attend them. Pedagogical courses were compulsory for all students who wanted to become AISCI professors. The university prepared teachers and professors of economics and business both for the pre-university and university level. Starting with academic year 1927-1928, the pedagogical courses become compulsory for all students enrolled in the $3^{\text {rd }}$ year. In addition, new courses were introduced for the commercial high school teachers. These were organized each year, in August and September.

"The Pedagogical Section" as the pedagogical department was called, has offered programs for AISCI students, graduates, and doctors interested in teaching economics and business subjects. The department offered different programs lasting between one and two years. The two-year program included courses, classes and practical activities (pedagogy, practical stages in schools, physics applied in commerce and industry, language, shorthand and typing). The one-year program consisted of class activities: commercial mailing (in French, English, German and Italian languages), shorthand and typing, commercial sciences, mathematics, physics and chemistry applied to merchandises, and judicial sciences. As part of their practical stages in schools, students had to teach classes at The Pedagogical Seminar for two years, during the $3^{\text {rd }}$ and $4^{\text {th }}$ years of studying.

The Pedagogical Seminar has continued to train teachers up to today, with disruptions caused by the Second World War and the changes in the Romanian society after the War. Changes in the teacher training programs were related with more formal aspects than just basic and content ones, so that important things such as quality orientation, strong economic, pedagogical and practical preparation, and respect for the teaching career, students, and quality work were kept and transmitted to students.

\subsection{The Teacher Training Department}

The Teacher Training Department (TTD) follows the pedagogical department and The Pedagogical Seminar. It had the support of the university administrators even in moments of difficulties for academic life such as the Second World War and after the War (1946-1948). It had the support of well-known prestigious professors, active as head of departments, or directors of the Pedagogical/Educational Sciences Institute.

ASE always recognized the value of economic and pedagogic education for the quality of teachers and of the education provided by them. As economists and promoters of the economic way of thinking, the members of the ASE academic community have understood the value of education as a positive externality with a high rate of return and, at the same time, have argued in favor of the need for highly qualified teachers who can develop the competences their current and future students will need.

\subsection{The Teachers' Education Programs}

As mentioned above, universities are in charge of training teachers in Romania. In order to be a teacher in Romania, a person needs to have a university degree and, in addition, a teaching certificate. Both diplomas are issued by universities, the last one after graduating from a TTD program. 


\subsubsection{The Initial Teacher Training}

In ASE, TTD courses are attended by a large number of students enrolled in bachelor, master and doctoral programs, both on campus or at a distance. Each year, TTD has about 1600-1700 students, 100-175 of them being master or doctoral students. TTD students are simultaneously or consecutively students in different schools of economics and business from ASE. First year students, both in bachelor and master programs in ASE, who have chosen a TTD program follow simultaneously economics and business bachelor or master programs and the psycho-pedagogical ones. All the others are attending the psycho-pedagogical programs consecutively with their major programs as post-graduate programs.

In Level 1 teacher training students enrolled in different schools of economics and business in ASE are receiving general psycho-pedagogical knowledge and all necessary information related to teaching economics subjects in compulsory education. Specific knowledge on economic education in schools is provided by courses and class activities in didactics of economics and economic/business subjects and practical stages in schools. Students spend three semesters to get this specific knowledge while they are discussing curriculum issues and the teaching process in economics/economic or business education classes.

Students become familiar with educational materials such as textbooks, teachers' and students' books developed for teachers and students for use in and outside of classes, including electronic resources. Among other class activities recommended for Level 1 students is a textbook evaluation in order to select the best textbook for a particular group of students from those available. Considerations include interest in studying economics, incentives to learn, expected performance level, family support, and other relevant aspects. It is a research-based activity involving students in collecting data about the published textbooks. They compare different criteria used to evaluate textbooks, select up to 10 criteria considered most relevant, develop a grid as an instrument of textbook evaluation and apply the grid to select the best economics textbook. The activity implies high-level thinking skills such as analysis and evaluation.

Economics and business lesson planning is another important component of pre-service teacher training at TTD. Students are trained to establish valuable instructional objectives and to propose students' complex achievements, starting with knowledge and moving up to evaluation and application (Bloom, 1956; Anderson, 2006). They become familiar with different methods and strategies of teaching in order to be able to design effective learning activities and properly plan different lessons. As part of their training students are actively involved in different attractive learning activities, such as simulations, play-roles, or games designed to learn important economic concepts such as market, price, profit, cost, productivity, demand and supply, or competition. Among these, the simulations of transactions on the market or production and consumption activities are used to demonstrate the value of active-learning teaching to increase students' motivation and achievements. At the end of the class, students should be confident in active teaching and, also, able to design themselves attractive activity-based economics lessons.

Students are trained to be able to evaluate learning achievements as well. Evaluation is as important as teaching due to its power to motivate students to learn. Based on their own learning experiences, TTD students recognize that they can easier accept imperfect teaching than incorrect assessment. In order to become good evaluators, students attend lectures on theory of assessment and participate in class activities in which they analyze and design assessment instruments for economics lessons and complete and grade tests.

At the end of the class, students participate in micro-teaching sessions. They apply all that they have learned by planning and teaching a 15-minutes class activity. The teaching experience continues in schools. In Level 1 teacher training they have to spend time to experience a teacher activity in school during two stages of teaching practice. The $1^{\text {st }}$ stage lasts 14 weeks and the $2^{\text {nd }}$ lasts 12 weeks. Both stages include class observation, teaching assistance, lesson planning and teaching. At the end of the practical stage two, students should be able to teach independently and to perform satisfactorily the roles a teacher has to play. At graduation, they will be certified as qualified teachers for compulsory education.

The Level 2 students are enrolled in a master program in ASE or have graduated from one (not necessary in ASE, but in economics or business or in other related domains of knowledge from schools of economics and business, such as public administration, law, or business communication). Students enrolled in a Level 2 program are prepared to teach in high schools/non-compulsory education. There are no clearly established requirements regarding the psycho-pedagogical background for university teaching staff. Universities are autonomous institutions and, based on this, each university has its own requirements, in addition to the legal ones which are considered a minimum. Universities encourage the teaching staff to attend and graduate from a psycho-pedagogical training program in order to improve their teaching competences and, at the 
same time, to meet the requirements of a national agency of quality assurance in higher education.

Level 2 means in-depth studies, both in the psycho-pedagogical domain and economic non-compulsory education. Students spend two semesters on non-compulsory economic education studies attending lectures on didactics in the economic domain and developments in didactics of specialties and participating in class activities and one more practical stage in schools. Lectures, discussions and class activities are oriented to contemporary issues on economic education, ways to improve adults' economic education, and, especially innovative teaching methods and strategies.

\subsubsection{The Continuous Teacher Training}

TTD is a center for in-service teacher training and professional development of pre-university teachers of economics and business subjects. Especially for them, TTD has $2^{\text {nd }}$ and $1^{\text {st }}$ teaching degrees programs. Almost half of the teachers of economics and business subjects in the country attend these programs. Regularly, TTD teaching degree programs are attended by teachers form five out of eight regions in Romania (North-East, South-Muntenia, Bucharest-llfov, South-Vest and Center). For $2^{\text {nd }}$ teaching degree candidates, TTD organizes courses each year, in July.

The number of in-service teachers of economics and business professionally trained at TTD seems to be low (Table 4. Teachers of economics and business enrolled in $2^{\text {nd }}$ and $1^{\text {st }}$ teaching degree programs at TTD), and especially if it is compared with the number of other subject teachers trained in similar centers. But, absolute figures might not be relevant by themselves; they have to be compared to the total number of teachers of economics and business subjects in pre-university education and with their percentage in terms of the total number of teachers. From all economics and business subjects taught in high schools, only economics and entrepreneurial education are part of the main core curriculum; in other words only these subjects are taught in every high school, no matter its profile (scientific, humanistic, artistic or vocational). But, they are taught only one hour per week, 35 weeks a year. Business subjects such as accounting, commerce, tourism, marketing, management, finance, or public administration are taught only in commercial vocational high schools, of which there are not many. For example in the capital city of Bucharest, which is the largest city in the country, only six out of more than 100 high schools are commercial vocational ones. As a consequence, the number of teachers of business subjects is low, relative to the total number of teachers.

Table 4. Teachers of economics and business enrolled in $2^{\text {nd }}$ and $1^{\text {st }}$ teaching degree programs at TTD

\begin{tabular}{|c|c|c|c|c|c|}
\hline \multirow{2}{*}{$\begin{array}{c}\text { The teaching } \\
\text { degree }\end{array}$} & Year & \multicolumn{2}{|c|}{ Number of teachers } & \multirow{2}{*}{$\begin{array}{c}\text { Absolute } \\
\text { variation }\end{array}$} & $\begin{array}{c}\text { Relative } \\
\text { variation }\end{array}$ \\
\cline { 2 - 6 } & Enrolled & Graduates & 7 & $27 \%$ \\
\hline $\begin{array}{c}\text { II Teaching } \\
\text { degree }\end{array}$ & 2012 & 26 & 19 & 2 & $10 \%$ \\
\cline { 2 - 6 } & 2013 & 20 & 18 & 5 & $18 \%$ \\
\cline { 2 - 6 } & 2014 & 28 & 23 & 3 & $9 \%$ \\
\cline { 2 - 6 } & 2015 & 32 & 29 & 6 & $25 \%$ \\
\hline \multirow{2}{*}{$\begin{array}{c}\text { I Teaching } \\
\text { degree }\end{array}$} & $2012-2014$ & 26 & 24 & 2 & $7,7 \%$ \\
\cline { 2 - 6 } & $2013-2015$ & 32 & 32 & 0 & $0 \%$ \\
\cline { 2 - 6 } & $2014-2016$ & 35 & 24 & 11 & $31 \%$ \\
\hline
\end{tabular}

Source: Cace, C; Lacatus, M. L.; Staiculescu, C.; 2017

Enrolling in the teaching degrees programs at TTD and attending the courses does not necessarily mean successfully graduating from them. The table above (Table 4) shows differences, sometimes important, up to $30 \%$, between the number of teachers enrolled in the program and the number of graduates (teachers who succeed to obtain the $2^{\text {nd }}$ or $1^{\text {st }}$ teaching degree at the end of the program). There are specific requirements for each teacher training program and competence standards for teacher candidates. A teaching degree 
represents a higher level of competence in teaching which can be described as an improvement from a good teacher to a very good, or exceptional, one. Than lowest grade to pass the $2^{\text {nd }}$ degree exam is eight (on a scale from 1 to 10), while to pass the $1^{\text {st }}$ degree exam a score of nine is required. In other words, graduates are likely to be highly qualified teachers, both in economics or business and in pedagogy, capable of motivating their students to learn and to adapt the instructional process to the students' needs, even if not in ideal situations.

\section{CONCLUSIONS}

The experience gained through more than 100 years of teacher training in economics and business is valuable to ASE, and ASE should continue to collect information both on initial and continuous teacher training provided by the university. TTD's good name is valuable as well. Despite all of the controversy regarding the quality and efficiency of current teacher training programs, we cannot say for certain that the system of teacher education is the problem and not the way in which it is sometimes implemented. In the case of ASE, the teacher education programs are conducted responsibly according to well-defined quality standards and with the intent of educating dedicated teachers of economics and business capable of delivering high quality economic education in schools. And this should continue no matter what changes the system of teacher education may occur. Right now, it seems that the necessary change is in to establish appropriate quality standards and to follow them, and to learn from good practices.

\section{REFERENCE LIST}

Badescu, G., Oana Negru-Subtirica, O., Angi, D. and Ivan, C. (2017). Profesor în Romania. Cine, de ce, in ce fel contribuie la educatia elevilor in scolile romanesti? In PERSPECTIVE | Friedrich Ebert Stiftung BUCUREȘTI. La http://library.fes.de/pdf-files/bueros/bukarest/14003.pdf

Bjekic D., Zlatic L. and Arsovic B.. (2018). Teacher education between new sciences. Journal of Educational Sciences and Psychology. Vol 1 (XLIII). No.1/2011.

Cace, C., Lacatus, M.L., Staiculescu, C, (2017). Quality assurance in the teacher training programs at university teacher training departments. Case study: Bucharest University of Economic Studies, in BASIQ International Conference: New Trends in Sustainable Business and Consumption - 2017, edited by Pamfilie, Rodica; Dinu, Vasile; Tachiciu, Laurențiu; Pleșea, Doru; Vasiliu, Cristinel, Proceedings of BASIQ Vol. 01

Caena, F. (2011). Education and Training 2020 Thematic Working Group 'Professional Development of Teachers'.Literature review Quality in Teachers' continuing professional development. At https://pdfs.semanticscholar.org/11c9/e90f3fb8a97e463882d5ab0846b2373279a2.pdf

Coalitia pentru Educatie. (2016). Masterat didactic sau modul psiho-pedagogic, https://issuu.com/coalitiaedu/docs/raport_formarea_initiala

Davidoglu, Anton. 1913. Cuvantare rostita la inaugurarea cursurilor Academiei Comerciale, in Nastase, Pavel si Zaharia, Razvan, coordonatori. 2015. Centenar ASE: memorii si documente, Ed. ASE, 2015, la http://ase.ro/ase105/centenar_ase_memorii_si_documente.asp

European Commision. (2018). Education and Training. Monitor. La https://ec.europa.eu/education/sites/education/files/document-library-docs/volume-1-2018-educationand-training-monitor-country-analysis.pdf

European Commission. (2018). Romania. Continuing Professional Development for Teachers Working in Early Childhood and School Education. At https://eacea.ec.europa.eu/nationalpolicies/eurydice/content/continuing-professional-development-teachers-working-early-childhood-andschool-education-61_enINSEE. (2014) Educatia in Romania. La http://www.insse.ro/cms/files/publicatii/pliante\%20statistice/Educatia_in_Romania_n.pdf

ISE. (2015). Raport privind starea invatamantului preuniversitar din Romania, la http://www.ise.ro/wpcontent/uploads/2015/08/Raport-starea-invatamantului-preuniversitar-2015-Site-ISE.pdf

Istudor, N. (2017). Raportul anual al Rectorului Academiei de Studii Economice din Bucuresti privind starea universitatii. 15 martie 2017, la http://www.ase.ro/2013_files/despre_ase/legislatie/strategia14- 
20/RAPORTUL\%20RECTORULUI\%202016.pdf

Luzuriaga, L. colectivo (2018). Formacion y evaluacion del prefesorado. At http://www.educacionyfp.gob.es/yosoyprofe/dam/jcr:d19f7bba-7b13-4c39-bc0f-6ed316579d86/c-Iluzuriaga-conclusiones-seminario\%20sobre\%20profesorado.pdf

Nastase, P., Rosca, I. Gh., coordonatori. (2013). Academia de Studii din Bucuresti. Un secol de existența. Ed. ASE, București, 2013, la http://ase.ro/ase105/ase-un-secol-de-existenta.asp

Presedentia Romaniei. (2018) Romania Educata. Http://www.romaniaeducata.eu/wpcontent/uploads/2018/11/Romania-Educata-Rapoarte.pdf

Rupérez, F. L. and Nasarre, E. (2011). La carrera profesional del profesorado. Una propuesta complementaria. Magistero 21. Suplemento professional. Http://www.educacionyfp.gob.es/yosoyprofe/dam/jcr:d19f7bba-7b13-4c39-bc0f-6ed316579d86/c-Iluzuriaga-conclusiones-seminario\%20sobre\%20profesorado.pdf

Nastase, P., Rosca, I. Gh., coordonatori. (2013). Academia de Studii din Bucuresti. Un secol de existenta. Ed. ASE, Bucuresti, 2013, la http://ase.ro/ase105/ase-un-secol-de-existenta.asp

Presedentia Romaniei. (2018) Romania Educata. Http://www.romaniaeducata.eu/wpcontent/uploads/2018/11/Romania-Educata-Rapoarte.pdf

Rupérez, F. L. and Nasarre, E. (2011). La carrera profesional del profesorado. Una propuesta complementaria. Magistero 21. Suplemento professional. Http://www.educacionyfp.gob.es/yosoyprofe/dam/jcr:d19f7bba-7b13-4c39-bc0f-6ed316579d86/c-Iluzuriaga-conclusiones-seminario\%20sobre\%20profesorado.pdf 